University of South Florida

DIGITAL COMMONS

Digital Commons @ University of

@ UNIVERSITY OF SOUTH FLORIDA

South Florida

KIP Articles

KIP Research Publications

January 2017

\title{
The World Karst Aquifer Mapping project: concept, mapping procedure and map of Europe
}

Zhao Chen

Augusto S. Auler

Michel Bakalowicz

David Drew

Franziska Griger

See next page for additional authors

Follow this and additional works at: https://digitalcommons.usf.edu/kip_articles

\section{Recommended Citation}

Chen, Zhao; Auler, Augusto S.; Bakalowicz, Michel; Drew, David; Griger, Franziska; Hartmann, Jens; Jiang, Guanghui; Moosdorf, Nils; Richts, Andrea; Stevanovic, Zoran; Veni, George; and Goldscheider, Nico, "The World Karst Aquifer Mapping project: concept, mapping procedure and map of Europe" (2017). KIP Articles. 5682.

https://digitalcommons.usf.edu/kip_articles/5682

This Article is brought to you for free and open access by the KIP Research Publications at Digital Commons @ University of South Florida. It has been accepted for inclusion in KIP Articles by an authorized administrator of Digital Commons @ University of South Florida. For more information, please contact digitalcommons@usf.edu. 


\section{Creator}

Zhao Chen, Augusto S. Auler, Michel Bakalowicz, David Drew, Franziska Griger, Jens Hartmann, Guanghui Jiang, Nils Moosdorf, Andrea Richts, Zoran Stevanovic, George Veni, and Nico Goldscheider 


\title{
The World Karst Aquifer Mapping project: concept, mapping procedure and map of Europe
}

\author{
Zhao Chen $^{1}$ • Augusto S. Auler ${ }^{2} \cdot$ Michel Bakalowicz $^{3} \cdot$ David Drew $^{4}$. \\ Franziska Griger $^{1}$ - Jens Hartmann ${ }^{5}$. Guanghui Jiang ${ }^{6}$. Nils Moosdorf ${ }^{7}$. \\ Andrea Richts ${ }^{8} \cdot$ Zoran Stevanovic $^{9} \cdot$ George Veni $^{10} \cdot$ Nico Goldscheider $^{1}$
}

Received: 27 June 2016 / Accepted: 10 December 2016 / Published online: 13 January 2017

(C) The Author(s) 2017. This article is published with open access at Springerlink.com

\begin{abstract}
Karst aquifers contribute substantially to freshwater supplies in many regions of the world, but are vulnerable to contamination and difficult to manage because of their unique hydrogeological characteristics. Many karst systems are hydraulically connected over wide areas and require transboundary exploration, protection and management. In order to obtain a better global overview of karst aquifers, to create a basis for sustainable international water-resources management, and to increase the awareness in the public and among decision makers, the World Karst Aquifer Mapping (WOKAM) project was established. The goal is to create a world map and database of karst aquifers, as a further development of earlier maps. This paper presents the basic concepts and the de-
\end{abstract}

This article describes a project supported by the International Association of Hydrogeologists (IAH) Commission on Karst Hydrogeology (www. iah.org/karst)

David Drew is retired from Trinity College Dublin

Nico Goldscheider

nico.goldscheider@kit.edu

1 Institute of Applied Geosciences, Division of Hydrogeology, Karlsruhe Institute of Technology (KIT), Kaiserstr. 12, 76131 Karlsruhe, Germany

2 Instituto do Carste, Rua Barcelona 240/302, Belo Horizonte, MG 30360-260, Brazil

3 HydroSciences, University of Montpellier, UMR5569 - CC0057, 163 rue Auguste Broussonet, 34090 Montpellier, France

4 Moheraroon, Kilfenora, Co. Clare, Ireland

5 Institute for Geology, Center for Earth System Research and Sustainability (CEN), University of Hamburg, Bundesstr. 55, 20146 Hamburg, Germany tailed mapping procedure, using France as an example to illustrate the step-by-step workflow, which includes generalization, differentiation of continuous and discontinuous carbonate and evaporite rock areas, and the identification of non-exposed karst aquifers. The map also shows selected caves and karst springs, which are collected in an associated global database. The draft karst aquifer map of Europe shows that $21.6 \%$ of the European land surface is characterized by the presence of (continuous or discontinuous) carbonate rocks; about $13.8 \%$ of the land surface is carbonate rock outcrop.

Keywords Hydrogeological mapping · Global water resources management $\cdot$ Carbonate rock $\cdot$ Karst $\cdot$ Europe

6 International Research Center on Karst (IRCK) under the Auspices of UNESCO and Key Laboratory of Karst Dynamics, Institute of Karst Geology, Guilin 541004, China

7 Department of Biogeochemistry/Geology, Leibniz Center for Tropical Marine Ecology (ZMT), Fahrenheitstr. 6, 28359 Bremen, Germany

8 Federal Institute for Geosciences and Natural Resources, Sub-Department, International Cooperation, Stilleweg 2, 30655 Hannover, Germany

9 Department of Hydrogeology, Centre for Karst Hydrogeology, Faculty of Mining \& Geology, University of Belgrade, Djusina 7, 11000 Belgrade, Serbia

10 National Cave and Karst Research Institute, 400-1 Cascades Avenue, Carlsbad, New Mexico 88220-6215, USA 


\section{Introduction}

According to an often-cited estimation by Ford and Williams (2007), approximately $20-25 \%$ of the global population depends largely or entirely on groundwater obtained from karst aquifers. In some countries and regions such as Austria, the Dinaric region (Europe) and Southwest China, karst water contributes $50 \%$ or more to regional freshwater supplies (Hartmann et al. 2014; Wu et al. 2009). Several large cities rely entirely or predominantly on karst aquifers such as San Antonio in Texas, USA (1.4 million inhabitants), Vienna in Austria (1.8 million), Rome in Italy (2.9 million) or Damascus in Syria (6-7 million; Al-Charideh 2012; Kresic and Stevanovic 2010).

Karst aquifers form in soluble rocks by flowing groundwater and are characterized by solutionally enlarged fractures, bedding planes and conduits, which form a hydraulically connected drainage network (Goldscheider and Drew 2007). Carbonate sedimentary formations including more than $75 \%$ of carbonate minerals such as limestone and dolomite, are the most important karstifiable rocks (Ford and Williams 2007). Karst also occurs in other rock types with predominantly carbonatic composition, including carbonatic conglomerates (Goeppert et al. 2011) and carbonatic metamorphic rocks (marble, calcite schist; Skoglund and Lauritzen 2011). Evaporitic formations, such as gypsum and anhydrite, are also highly karstifiable. Under exceptional hydro-climatic conditions, karst phenomena can also form in other rock types such as quartz sandstone or quartzite (Piccini and Mecchia 2009).

Because of their unique hydrogeological characteristics, karst aquifers are particularly vulnerable to human impacts (Drew and Hötzl 1999) and are difficult to manage (Stevanovic 2015). In exposed karst systems, contaminants can easily enter the subsurface, often via thin soils and open fractures, and rapidly spread in the conduit network. Nonexposed karst aquifers (i.e. concealed, confined or artesian aquifers) are better protected against direct contamination from the land surface. However, contaminant releases from deeper sources can also result in widespread contamination of these valuable freshwater or thermal-mineral water resources (Goldscheider et al. 2010). Because of their hydrogeologic heterogeneity, karst aquifers are difficult to exploit by means of drilling wells, which are often unproductive if they do not succeed in encountering water-bearing fractures, bedding planes or conduits. Historically, karst springs have been more favorable for freshwater abstraction, but they show high fluctuations of both discharge and water quality (Bakalowicz 2005; Kresic and Stevanovic 2010).

Many karst aquifers are connected over large areas and often constitute transboundary aquifer systems. The Dinaric Karst System is shared between northeast Italy, Slovenia, Croatia, Serbia, Bosnia and Herzegovina, Montenegro, Macedonia and Albania (Bonacci 1987; UNESCO-IHP
2013). The Mt. Hermon karst aquifer system, which is situated in the border region between Syria, Lebanon and Israel, feeds the springs of the Jordan River (Rimmer and Salingar 2006). One of the world's largest karst regions in Southwest China, covering about $540,000 \mathrm{~km}^{2}$, is shared between seven Chinese provinces and extends across the border to Vietnam (Guo et al. 2013). These examples highlight the need for fully integrating water-resources maps.

In the context of international water management under the conditions of climate change and population growth, the need of water resources maps at the global scale becomes even more evident. For example, some previously published maps focus on precipitation and the atmospheric water cycle (Kubota et al. 2007), river networks (Yamazaki et al. 2009), dams and reservoirs (Lehner et al. 2011) or other relevant aspects. A map of "Groundwater Resources of the World" (Richts et al. 2011; WHYMAP 2008) has been prepared within the framework of the World-wide Hydrogeological Mapping and Assessment Programme (WHYMAP) coordinated by UNESCO-IHP (BGR 2016). This map differentiates major groundwater basins, areas with local and shallow aquifers, and areas with complex hydrogeological structure, but does not include explicit information on karst aquifers.

The first relevant world map of carbonate rocks was published by Ford and Williams (1989). A revised version was prepared by Williams and Ford (2006) and used in Ford and Williams (2007). Version 3.0 of this map is available online (Williams and Fong 2016). This map differentiates between continuous and discontinuous carbonate rock areas. The total global distribution of evaporite rocks, most of which are confined by overlying sedimentary formations, was mapped by Kozary et al. (1968). Hollingsworth (2009) prepared a comprehensive map and database on Karst Regions of the World (KROW) that includes different types of karst (carbonate karst, evaporite karst and pseudokarst), along with other relevant information.

In summary, the existing global groundwater resources map does not display karst aquifers, whereas existing karst maps do not present detailed information on aquifers and groundwater resources, and are also not sufficiently detailed to be presented at the scale of WHYMAP products. Therefore, the World Karst Aquifer Mapping (WOKAM) project was established in 2012 and the map will be printed in 2017. The goal of this project is to prepare a world map of karst aquifers that helps to address global water-resources management and to increase the awareness of these valuable but vulnerable freshwater supplies. The World Karst Aquifer Map (the acronym WOKAM is used both for the project and the map) shall be compatible and complementary to other maps of the WHYMAP series, in particular the Groundwater Resources of the World map (Richts et al. 2011). As with other WHYMAP products, the final map shall be printed at two different scales, 1:25 million and 1:40 million, but will also 
be available in digital form for further usage such as hydrological modelling attempts at a global scale. As in other WHYMAP products, WOKAM uses the Sphere Robinson projection, which was also used for all maps in this manuscript. The digital Global Lithological Map (GLiM) by Hartmann and Moosdorf (2012) served as an important basis for WOKAM. GLiM is also available as a printed map (Moosdorf and Hartmann 2015).

WOKAM is a project of the International Association of Hydrogeologists' (IAH) Karst Commission and is financially supported by IAH and UNESCO, in the framework of the WHYMAP programme, with special cooperation of the WHYMAP team at the German Federal Institute for Geosciences and Natural Resources (BGR). The project is coordinated and processed at the Karlsruhe Institute of Technology (KIT). An international scientific advisory board (SAB), composed of the co-authors of this paper, met three times to define the mapping procedure and evaluate the progress of the project. The SAB also contributed to the global collection of data on springs and caves, with the support of numerous colleagues in many different countries (see acknowledgements). The project was implemented using a geographical information system (GIS), but also required many manual work steps.

\section{Basic mapping approach and legend}

The World Karst Aquifer Map is intended to focus on groundwater resources in karst aquifers, which develop primarily in carbonate rocks. Evaporites also constitute important karst systems in some regions, although high sulfate concentrations often hamper their direct utilization as drinking-water sources. Based on hydrogeologic observations internationally and a broad supporting literature, rocks that contain at least $75 \%$ of carbonate minerals are typically karstifiable (Ford and Williams 2007). In this paper, the term "carbonate rocks" is exclusively used for such "pure" carbonate rocks. GLiM and other globally available data sources do not provide explicit information on the percentage of carbonate minerals; however, lithological terms, such as limestone, dolomite or chalk, usually indicate "pure" carbonate rocks. Although the actual degree of karstification can vary greatly as a function of different geological and climatological factors (Goldscheider and Drew 2007), it is safe to assume that exposed carbonate rocks are karstified at least to some degree, unless proven otherwise. The following four principal mapping units were defined (Fig. 1):

- Carbonate rocks (sedimentary or metamorphic)

- Evaporites

- Other sedimentary formations

- Other metamorphic rocks and igneous rocks

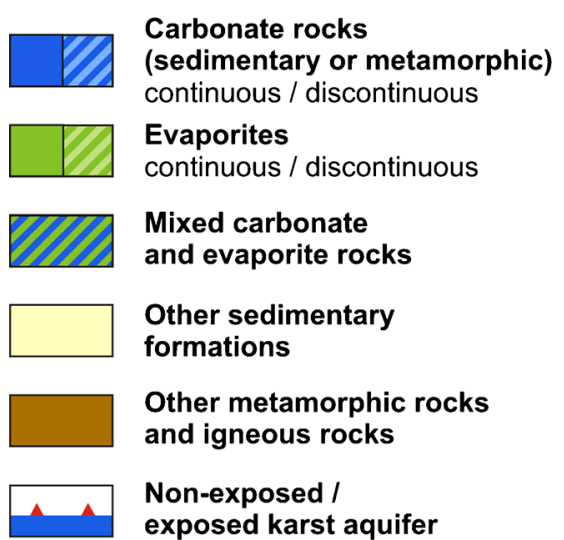

Fig. 1 Draft legend of the World Karst Aquifer Map, displaying signatures for lithological units. The definition and representation of exposed and non-exposed karst aquifers is illustrated in Fig. 2

Carbonate and evaporite rocks are further subdivided into continuous and discontinuous; the underlying rationale and details of this subdivision are described below. Areas formed by mixed carbonate and evaporite rocks (more than $15 \%$ of each rock type) are also displayed on the map.

The mapping units "carbonate rocks" and "evaporites" represent potential karst aquifers. Their actual degree of karstification and hydraulic properties cannot be determined consistently at a global scale; however, it is a defensible approach to assume that most exposed carbonate and evaporitic rocks represent karst aquifers. Biochemical sedimentary formations, such as limestone and dolomite, are the most widespread carbonate rocks. Chalk is a pure but fine-grained biogenic carbonate rock and often not considered to be karstifiable; however, many chalk aquifers are actually karstified, although karst features are less prominent than in classical limestone karst. In many regions, chalk aquifers contribute substantially to freshwater supplies (Maurice et al. 2006). Metamorphic carbonate rocks such as marble and calcite schist, also constitute important karst aquifers in some regions of the world. There is a smooth transition between diagenesis and metamorphosis and thus between sedimentary and metamorphic rocks. Therefore, this mapping unit includes the whole range of carbonate rocks, as defined in the preceding (i.e. more than $75 \%$ carbonate minerals).

The mapping unit "other sedimentary formations" includes both consolidated and unconsolidated rocks, mostly noncarbonate siliciclastic formations such as alluvial sediments and sandstone, but also mixed rock types (typically with less than $75 \%$ carbonate minerals) such as marl. This generalization was done to keep the map simple and to overcome inconsistencies at national borders on the GLiM map. Areas where other sedimentary formations outcrop at the land surface may include karst aquifers at greater depth. Zones where exposed carbonate rocks plunge under adjacent other sedimentary formations are highlighted by a line of red triangles pointing to the direction of non-exposed carbonate rocks (Fig. 2). No 
a

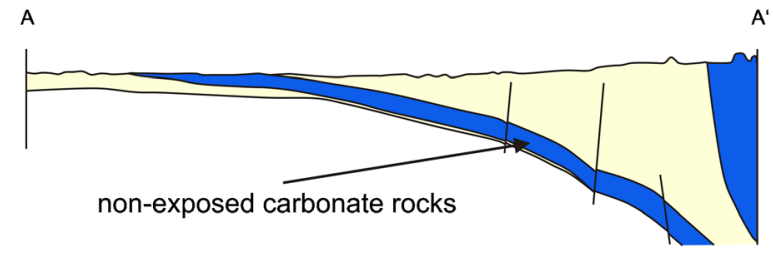

b

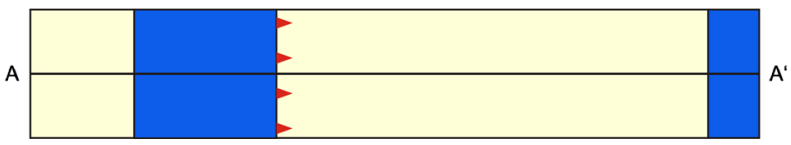

Fig. 2 Illustration of non-exposed karst aquifers: a cross-section; b plan view; the line of red triangles points to the direction of non-exposed carbonate rocks, but the plan view map does not provide detailed information concerning the areal extent or depth of these deep aquifers; for legend see Fig. 1

attempt is made to characterize those areas, beyond identifying their presence, which may include deep or artesian karst aquifers with fresh or thermal-mineral water. Exposed carbonate rocks usually form karst landscapes with more or less developed karst landforms such as dolines, and intense surface-groundwater interaction, which is usually not the case for non-exposed carbonate rocks, unless the overlying formations are very thin.

Crystalline rocks comprise igneous rocks and metamorphic rocks, which can be subdivided into metasediments and metaigneous rocks. Metasediments include karstifiable metamorphic carbonate rocks, which belong to the mapping unit "carbonate rocks," as described in the preceding. Therefore, the last mapping unit includes "other metamorphic rocks" such as gneiss, amphibolite and different types of schist; and igneous rocks, which encompass plutonic rocks such as granite and diorite; and volcanic rocks such as basalt, andesite and rhyolite. Some volcanic rocks, particularly basaltic lava flows with cooling fractures and lava tubes, show similar hydraulic properties to carbonate rocks (Kauahikaua et al. 1998), but they are usually not classified as karst aquifers and not delineated on WOKAM. The detailed work-steps from GLiM to WOKAM are described further in the following.

As the World Karst Aquifer Map is intended to provide relevant information for water resources management, selected important karst springs, wells and other water abstraction structures are also presented on the map. The presence of such springs and other karst water sources is also clear evidence for the existence of high-yielding karst aquifers. Therefore, the presentation of springs on the map is also an indirect way of indicating the hydraulic properties of the karst aquifers. Additionally, the map displays selected caves, because caves are characteristic of karst and generally represent the degree of karstification, which cannot be mapped otherwise at a global scale. The selection criteria for caves considers their hydrological importance, i.e. caves related to relevant water resources are preferentially presented on the map. The detailed selection criteria and the structure of the spring and cave database are described further in the following.

\section{Detailed mapping procedure}

\section{Database and workflow}

The major challenge in preparing the World Karst Aquifer Map is the extremely heterogeneous cartographic databases. The Global Lithological Map (GLiM) by Hartmann and Moosdorf (2012) was assembled from 92 regional geological maps (typically national maps) with different scales and mapping units, which were merged in a geographical information system (GIS). GLiM achieved a consistent legend by regrouping and reclassifying the numerous mapping units of the regional maps, while keeping much of the more detailed basic information in the associated database, which includes three levels of information. However, as GLiM was initially not intended to be published as a printed map, it does not have a defined and consistent scale, and the map was not generalized; furthermore, the authors of GLiM did not attempt to correct the available maps, which also means that there are some inconsistencies at state borders in terms of spatial delineation of polygons and their geologic attribution. In order to achieve a globally consistent world karst aquifer map suitable for printing at defined scales (1:25 million and 1:40 million), a well-defined workflow at a consistent working scale of 1:10 million was established and implemented (Fig. 3).

\section{Reclassification of mapping units}

Figure 4 displays the global lithological maps with its 13 lithological first-order mapping units and a detail of the map that is used as an example area to illustrate the detailed work steps from GLiM to WOKAM. The first step (illustrated in Fig. 4c) is the reclassification of the $13 \mathrm{GLiM}$ units into the four principal WOKAM mapping units, as follows (the symbols are explained in the caption of Fig. 4):

- SC refers to carbonate rocks

- EV refers to evaporites

- SU, SS, SM and PY refer to other sedimentary formations

- MT, PA, PI, PB, VA, VI and VB refer to other metamorphic rocks and igneous rocks

As a first approximation, the resulting map nicely displayed the distribution of carbonate rocks (Fig. 4c) but still included several problems: (1) some important carbonate rock and karst areas were not displayed, as they were hidden in the GLiM mapping unit "mixed sedimentary rocks" (SM); (2) some regionally important metamorphic carbonate rocks were entirely missing; (3) there was no uniform scale and no 
Fig. 3 Work flow of the mapping procedure from the Global Lithological Map (GLiM) to the World Karst Aquifer Map (WOKAM)

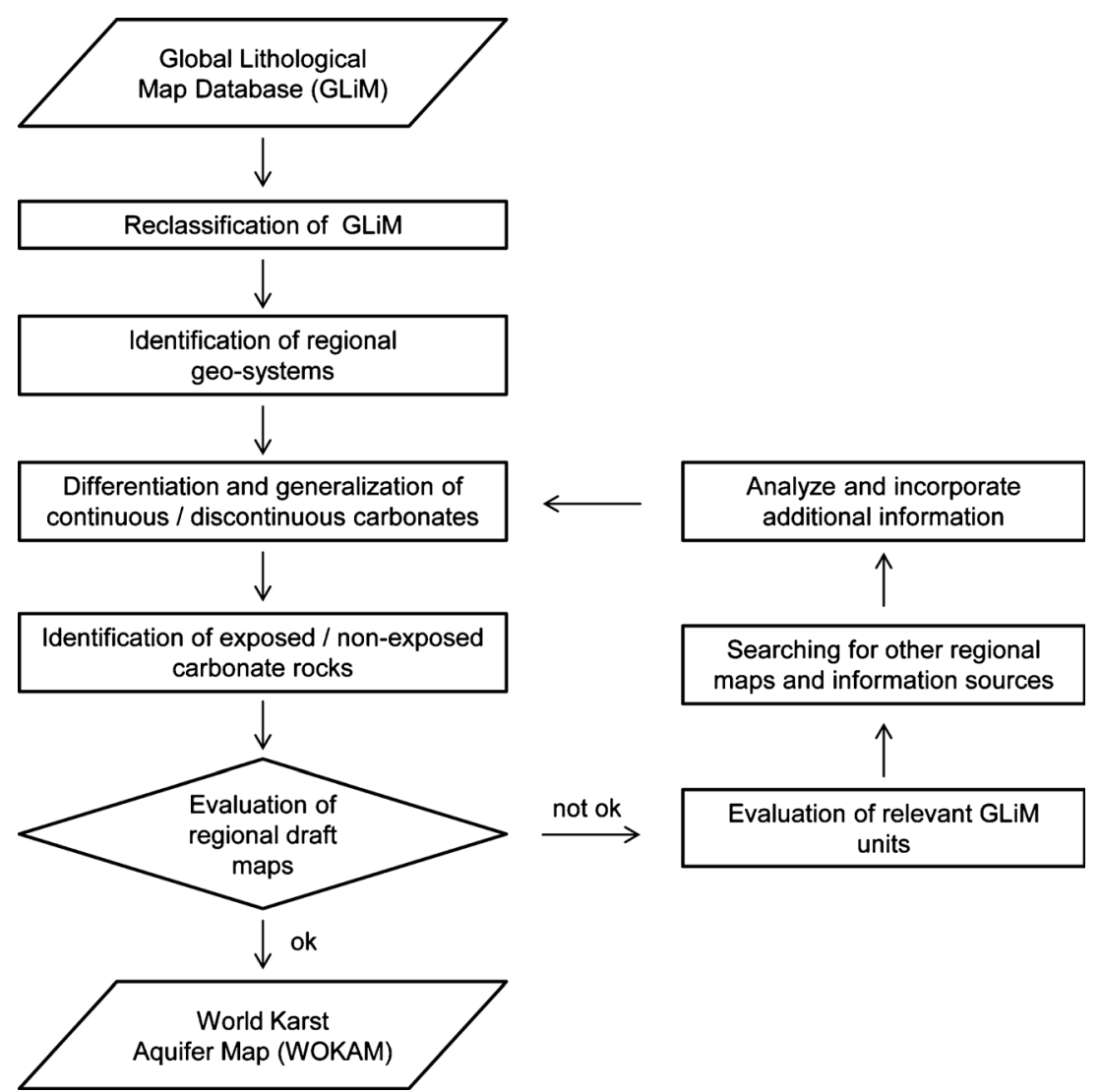

consistent generalization; therefore, additional work steps were required.

\section{Differentiation and generalization of continuous and discontinuous carbonates}

he evaluation of available GIS options revealed that a hydrogeologically meaningful generalization could not be done in an automatized way but required hydrogeological expertise and manual processing. In order to achieve a spatial framework for generalization, the map was divided into regional geo-systems based on the US Geological Survey (USGS) map of Geologic Provinces of the World (USGS 2016; Fig. 5). A geo-system is defined as a spatial entity with common geologic and geomorphologic attributes.

Integrative generalization of the map was done manually, at a consistent working scale of 1:10 million. An inherent problem in generalization is the existence of outcrops that are too small to be displayed individually, but too important to be ignored. To overcome this problem, carbonate (and evaporite) areas were subdivided into continuous and discontinuous, based on an area's share of the respective rock type. Wherever possible, the mapping unit "continuous" was applied, even for small polygons, because this is straightforward and readily understood. Polygons classified as "continuous" often include small patches or thin strips of non-karst surfaces that are too small to be displayed on the generalized map. By comparing the original, non-generalized polygons with the generalized ones, it turned out that the share of carbonate rocks was generally larger than $65 \%$, so this threshold was taken as lower limit for "continuous" carbonate rocks. Some areas contain many tiny, scattered or ramified carbonate rock polygons that cannot be displayed individually on the generalized map; therefore, the mapping unit "discontinuous" was introduced. By testing this approach in several regions, it turned out that the limits of 15 and $65 \%$ result in a meaningful generalization, both scientifically and in terms of graphical presentation; thus, areas with more than $65 \%$ of carbonate (or evaporite) rock were mapped as "continuous," whereas areas between 15 and 65\% were mapped as "discontinuous." However, because of the heterogeneity of the underlying database, and due to the diversity and complexity of different geological provinces, this general rule had to be adapted individually during the process of manual generalization, while consulting available geological and hydrogeological literature for the respective regions. Figure 6 illustrates the differentiation of areas of "continuous" and "discontinuous" carbonate rock during generalization; some of the hydrogeologically important but geologically complex and spatially compartmentalized karst systems in southern France are mapped as a region of discontinuous karst. 


\section{a}

b

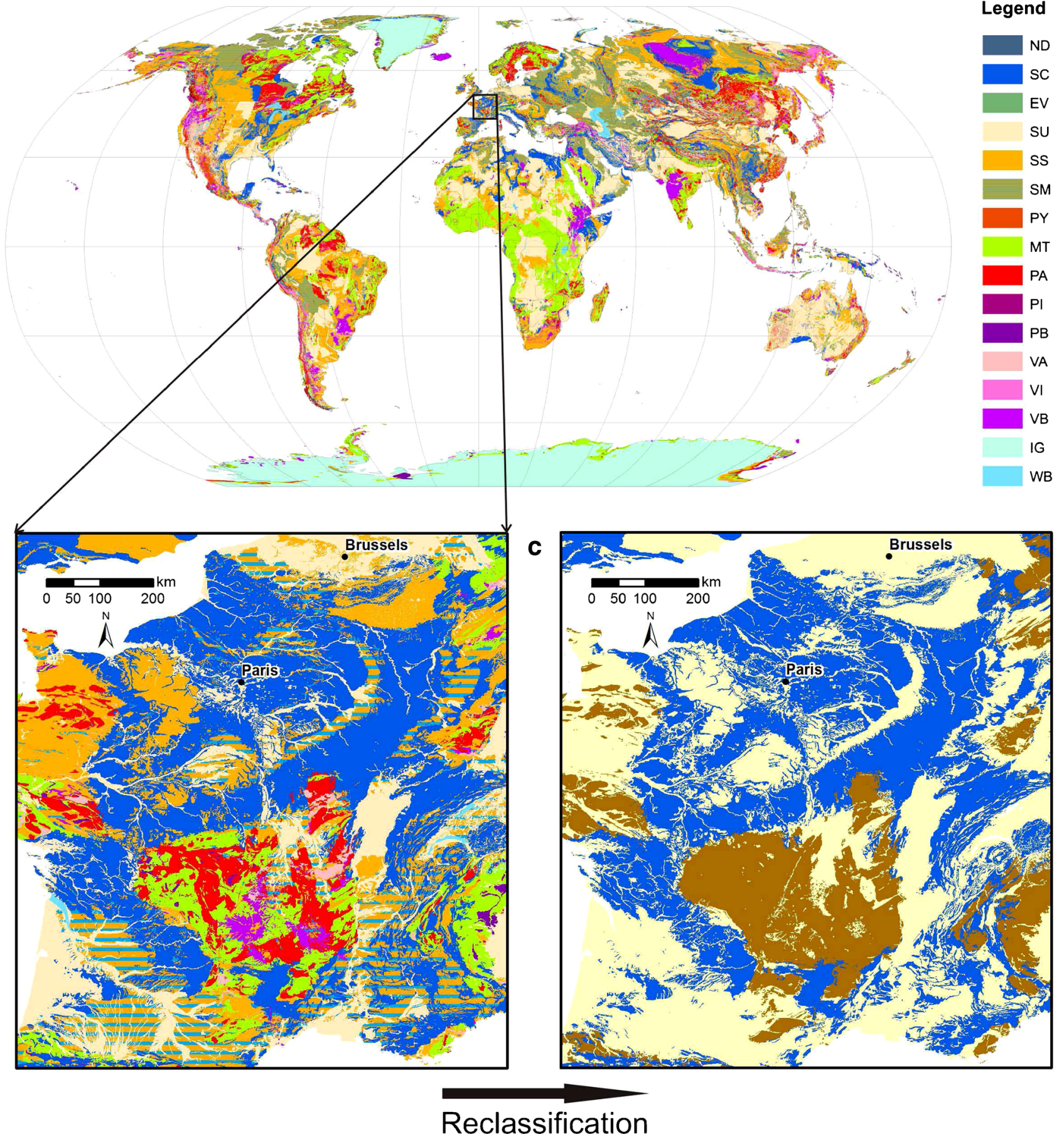

Fig. 4 a Original GLiM map and mapping units $(N D$ no data, $S C$ carbonate sedimentary rocks, $E V$ evaporites, $S U$ unconsolidated sediments, $S S$ siliciclastic sedimentary rocks, $S M$ mixed sedimentary rocks, $P Y$ pyroclastic rocks, $M T$ metamorphic rocks, $P A$ acid plutonic rocks, $P I$ intermediate plutonic rocks, $P B$ basic plutonic rocks, $V A$ acid

\section{Identification of non-exposed carbonate rocks}

The next step was the identification and presentation of nonexposed carbonate rocks, which constitute potential deep and confined aquifers, as illustrated in Fig. 2. As this work step requires three-dimensional geological analysis, it could not be volcanic rocks, $V I$ intermediate volcanic rocks, $V B$ basic volcanic rocks, $I G$ ice and glaciers and $W B$ water bodies); b Detail of GLiM for the example area; c Reclassification into WOKAM mapping units; for legend see Fig. 1

implemented automatically on the basis of two-dimensional information available in the GLiM database. Therefore, the geological setting of all relevant karst areas was assessed manually on the basis of the geo-system approach illustrated in Fig. 5. Regional geological maps, profiles and literature were consulted for all geo-systems in order to identify regionally 


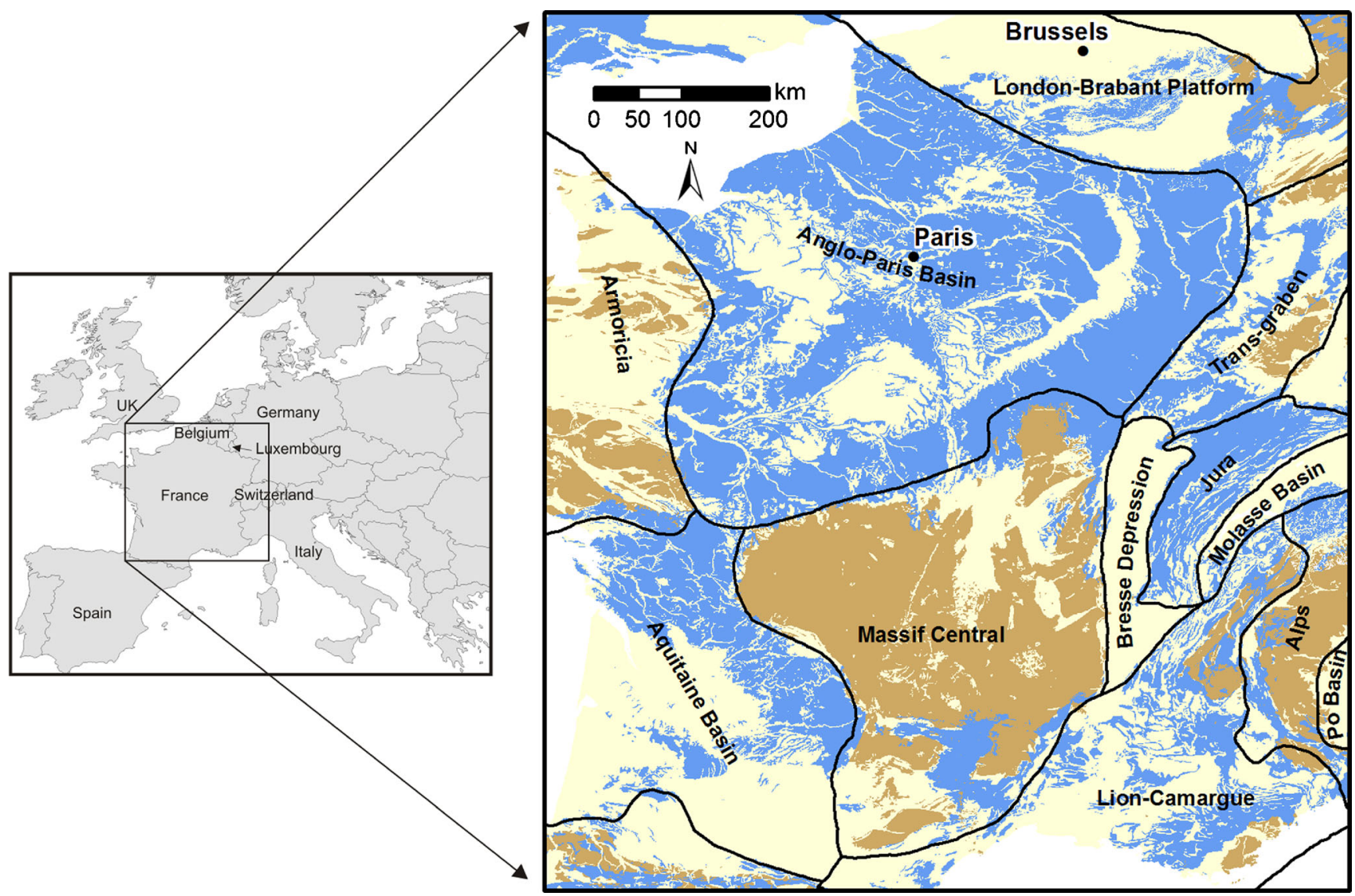

Fig. 5 Identification of regional geo-systems based on USGS (2016), which are used as a basis for hydrogeologically meaningful generalization; for legend see Fig. 1

a

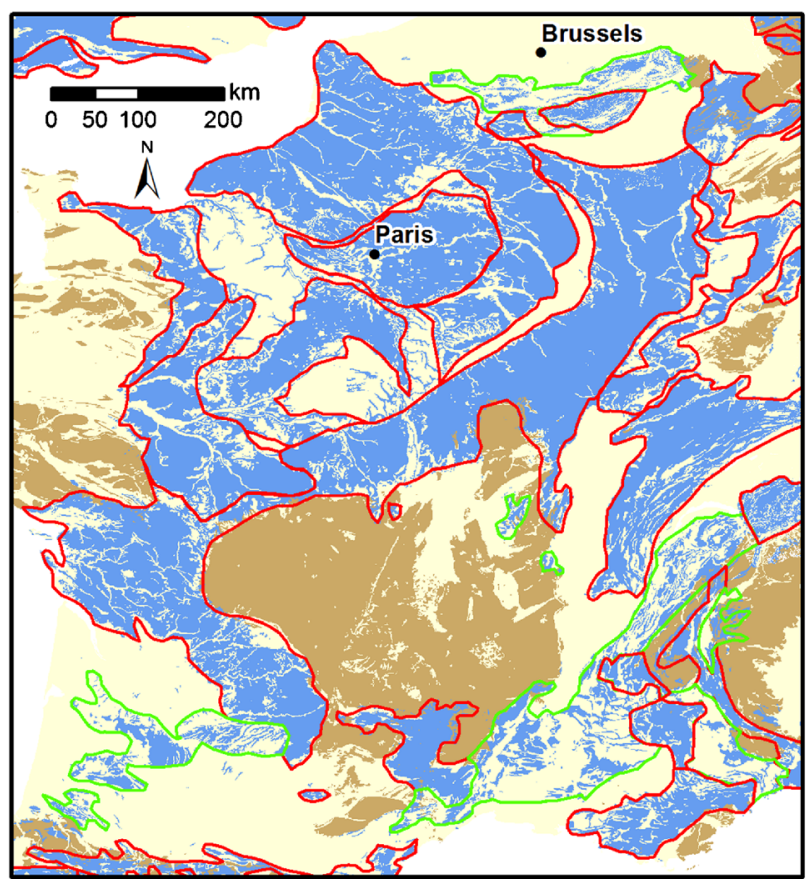

Fig. 6 Differentiation of continuous and discontinuous carbonate rocks during the process of manual generalization at a working scale of 1:10 million: a Original polygons with red and green lines that were used to b

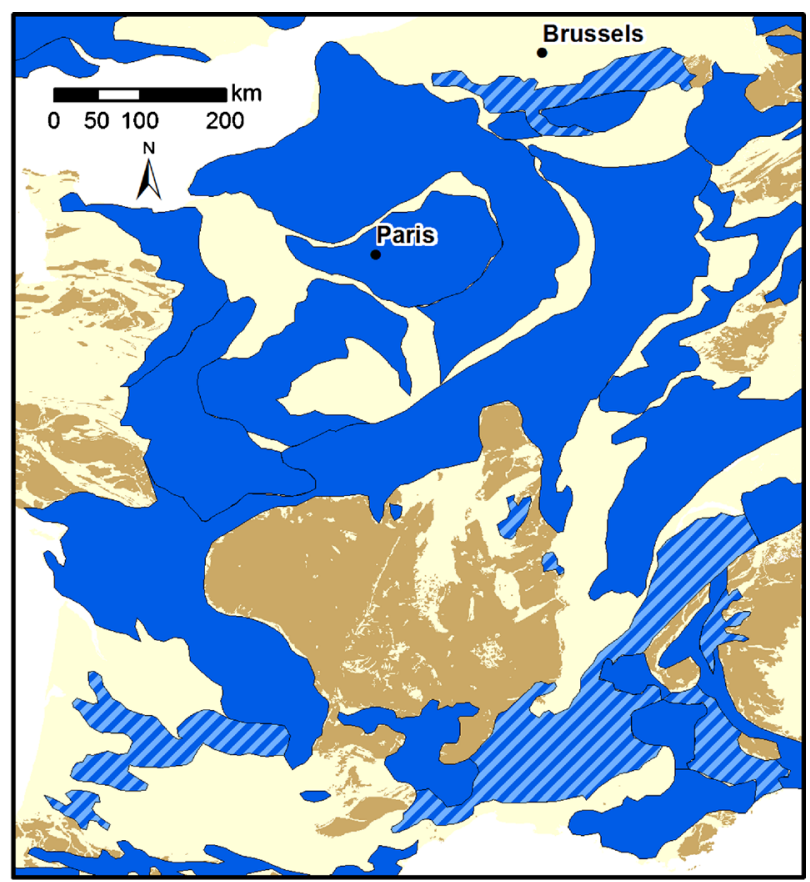

delineate areas of continuous and discontinuous carbonate rocks; b Generalized polygons; for legend see Fig. 1 
important non-exposed karst systems, such as the Paris Basin (France) highlighted in Fig. 7.

\section{Evaluation and iterative improvement of the map}

At different stages of the mapping procedure, the intermediate results were discussed by the $\mathrm{SAB}$ and sent to regional experts for evaluation and correction. In the case of negative evaluations, the map was further improved by searching and consulting additional and more accurate maps and information sources for the respective region until a satisfactory result was achieved (Fig. 3). It turned out that many polygons needed to be reclassified and rearranged. In particular, the initial delineation of carbonate rock areas was often insufficient, because many important karst areas were hidden under "mixed sedimentary rocks" (SM), and some areas consisting of "metamorphic rocks" (MT) also include large areas of carbonatic meta-sediments. For most countries and regions, it was possible to make these corrections based on GLiM. For other countries, GLiM was largely replaced by information obtained from regional or national maps. This was the case for Bulgaria (Beron et al. 2006), Hungary (Hungarian Ministry of Interior 2016), Italy (Sivelli and De Waele 2013), Moldova (Duscher et al. 2015), Portugal (Almeida et al. 1995), Romania (Orășeanu and Iurkiewicz 2010), Serbia (Stevanovic and Jemcov 1996), Slovenia (Ravbar and Šebela 2015), Spain (Ayala-Carcedo 1986), Switzerland (Jeannin 2016), and Ukraine (A. Klimchouk, Institute of

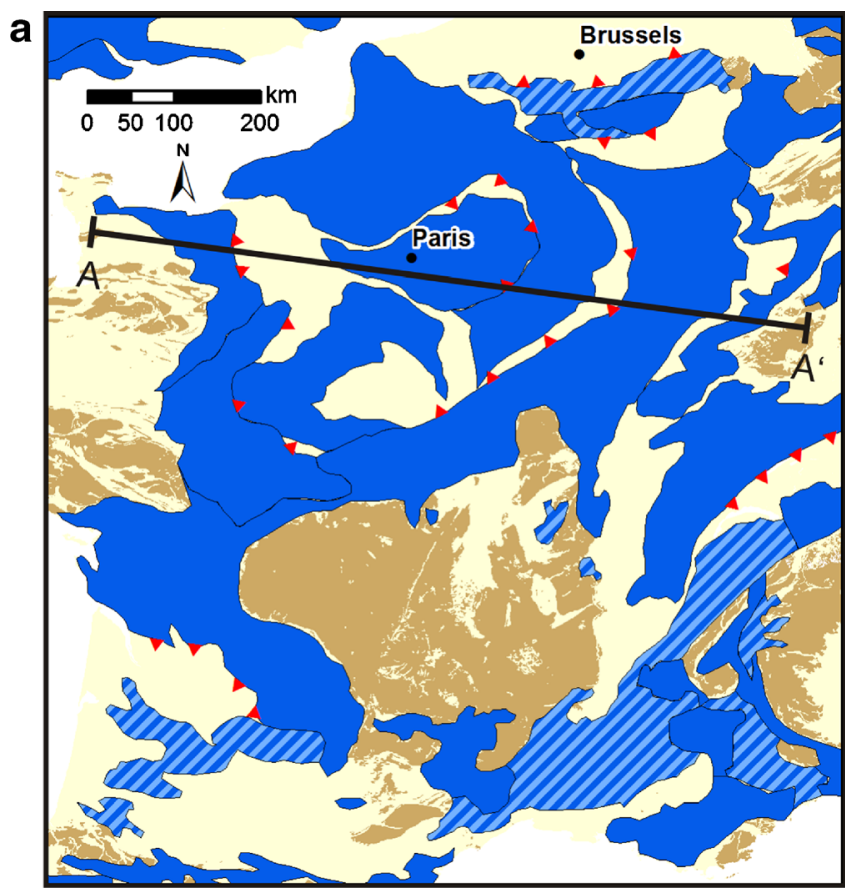

Fig. 7 Identification and presentation of non-exposed karst aquifers on the map, exemplified by the Paris Basin: a Karst aquifer map of France, where the red triangles point toward non-exposed carbonate rocks, illustrating the basin structure in this regionally important multi-karst-aquifer
Geological Sciences, National Academy of Sciences of Ukraine, personal communication, 2016).

\section{Karst water sources and cave database}

\section{Karst water sources database}

Several textbooks include tables or other information on major karst springs in the world (e.g. Ford and Williams 2007; Kresic and Stevanovic 2010) or in specific regions or countries. However, for the preparation of a world karst aquifer map, the available information was insufficient; therefore, a systematic global database on springs and other karst water sources was established in the framework of the WOKAM project. The major inherent challenges in creating this database were:

1. The amount and quality of available data and information for different countries is extremely variable (e.g. excellent data for Switzerland, almost no data for Africa).

2. The frequency and size-range of springs is also extremely unevenly distributed (e.g. many large springs in the Dinaric Karst, very few large springs in South America and Africa).

Only a limited amount of information can be displayed on a global map, whereas it is possible and useful to establish a

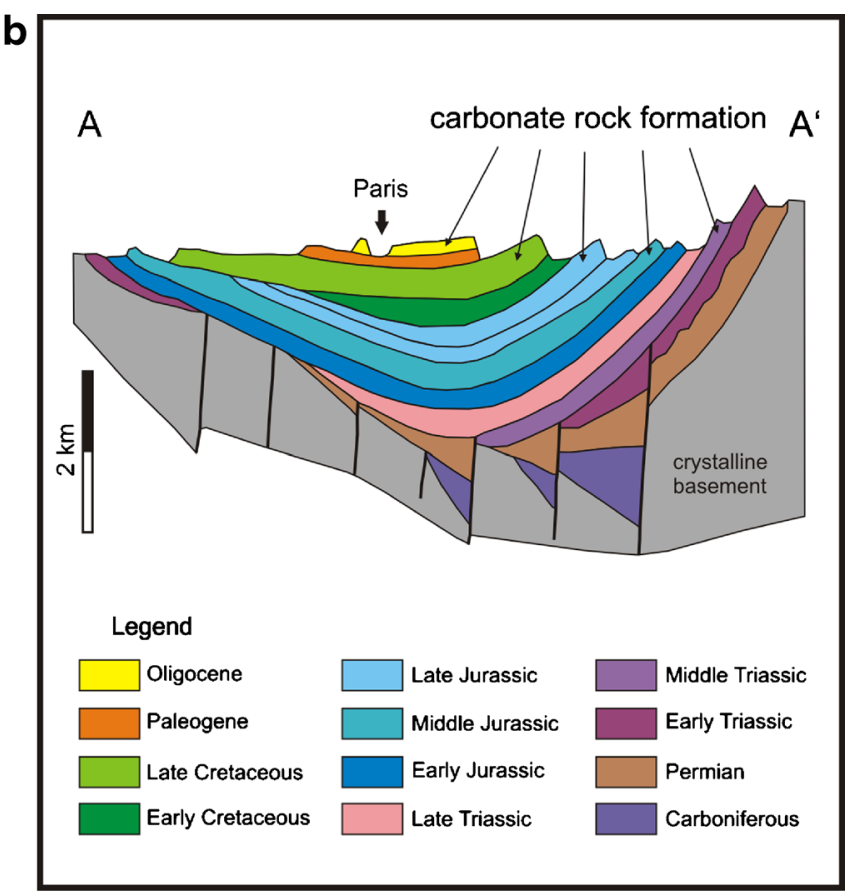

system; b Geologic profile across the Paris Basin (after Beccaletto et al. 2011) that was used to identify non-exposed karst aquifers in this geoprovince 
Table 1 Rating system for cave data evaluation: 5 out of 10 points are related to the dimensions of a cave, which always reflects the degree of exploration; the remaining 5 points are assigned for different aspects describing the significance of the cave and its associated water resources. Touristic or archaeological values are not considered

\begin{tabular}{lll}
\hline Rating section & $\begin{array}{l}\text { Rating } \\
\text { points }\end{array}$ & Rating criterion \\
\hline Length & 0 & $<10 \mathrm{~km}$ \\
& 1 & $10-50 \mathrm{~km}$ \\
& 2 & $50-100 \mathrm{~km}$ \\
& 3 & $>100 \mathrm{~km}$ \\
Depth & 0 & $<500 \mathrm{~m}$ \\
& 1 & $500-1,000 \mathrm{~m}$ \\
Hydrological significance & 0 & $>1,000 \mathrm{~m}$ \\
& 1 & No particular hydrological relevance (mostly dry cave) \\
Significance for human use & 0 & Associated with relevant springs, swallow holes or cave streams \\
and ecosystems & 1 & No particular importance \\
& & Cave water (spring/stream) has major importance for human use \\
Regional significance & 0 & and/or ecosystems \\
& 1 & Low to moderate regional significance \\
& 2 & Very high (e.g. longest cave in Africa, deepest cave in the world, only \\
& & available water resource in a large region) \\
\hline
\end{tabular}

detailed global database of karst water sources. Therefore, a pragmatic approach was followed: (1) detailed data collection for the database (in progress); (2) generalized presentation of selected karst water sources on the map. A template for data collection was designed and sent to SAB members and regional experts. The template allows inclusion of the following information: name and type of object (e.g. normal karst spring, thermal spring, submarine spring, water well), country and region, coordinates and elevation, relevant discharge data, information on water chemistry and temperature, information on aquifer geology, regional significance, comments, references.

Many karst springs are characterized by high variations in discharge; some springs run dry during droughts but have extremely high maximum discharges (often $>$ $100 \mathrm{~m}^{3} / \mathrm{s}$ ) following periods of high precipitation; however, in terms of water resources, the permanent (i.e. minimum) spring discharge is the most relevant quantity. In some remote and humid karst regions, many large karst springs are often not used (and sometimes not even known), whereas a relatively small karst spring in an arid region might be extremely important and well known (e.g. the springs of the Jordan River).

Based on these considerations, two main criteria were applied for inclusion of a particular karst water source on the map: the low-flow discharge of the spring (or pumping rate of the well), and its regional significance. The low-flow discharge is ideally calculated as the average annual minimum discharge, based on long-term data series; however, in most cases, such time series are not available. For many springs (e.g. in China and South America), only a single value is available, often measured during the dry season. In these cases, the dry

Table 2 Application of the rating system in Table 1, exemplified by five important caves in Europe, the USA and Africa

\begin{tabular}{|c|c|c|c|c|c|c|c|c|c|}
\hline \multirow[t]{3}{*}{ Name } & \multirow[t]{3}{*}{ Country } & \multirow{3}{*}{$\begin{array}{l}\text { Length } \\
{[\mathrm{km}]}\end{array}$} & \multirow{3}{*}{$\begin{array}{l}\text { Depth } \\
{[\mathrm{m}]}\end{array}$} & \multicolumn{6}{|c|}{ Weighted rating system for evaluation } \\
\hline & & & & Length & & $\begin{array}{l}\text { Hydrological } \\
\text { significance }\end{array}$ & $\begin{array}{l}\text { Human use and } \\
\text { ecosystems }\end{array}$ & $\begin{array}{l}\text { Regional } \\
\text { significance }\end{array}$ & SUM \\
\hline & & & & $\begin{array}{l}0-3 \\
\text { pts }\end{array}$ & $\begin{array}{l}0-2 \\
\text { pts }\end{array}$ & $0-2 \mathrm{pts}$ & $0-1 \mathrm{pts}$ & $0-2 \mathrm{pts}$ & $\begin{array}{l}0-10 \\
\text { pts }\end{array}$ \\
\hline Blauhöhle & Germany & 10.5 & 130 & 1 & 0 & 2 & 0 & 1 & 4 \\
\hline Riesending & Germany & 19.2 & 1,148 & 1 & 2 & 1 & 0 & 1 & 5 \\
\hline Mammoth Cave & USA & 643.7 & 124 & 3 & 0 & 2 & 1 & 2 & 8 \\
\hline $\begin{array}{l}\text { Siebenhengste-Hohgant } \\
\text { Cave System }\end{array}$ & Switzerland & 157.0 & 1,340 & 3 & 2 & 1 & 0 & 1 & 7 \\
\hline Sof Omar Cave & Ethiopia & 15.1 & 15 & 1 & 0 & 2 & 1 & 2 & 6 \\
\hline
\end{tabular}




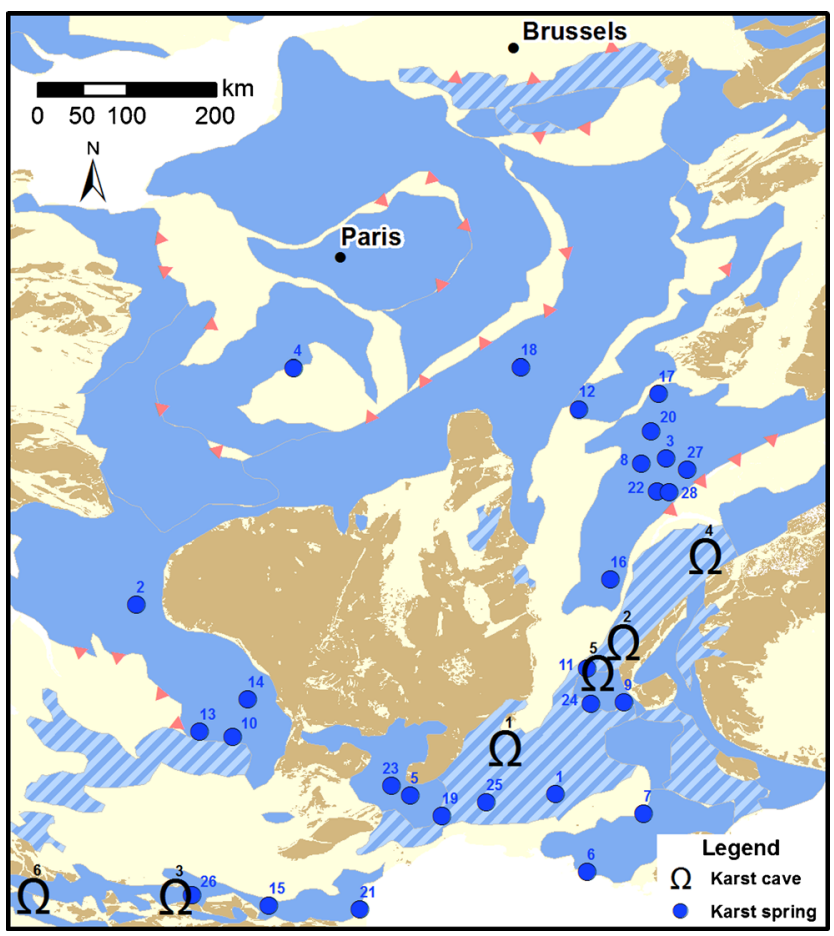

Fig. 8 Draft karst map of the example area (France) with presentation of selected springs and caves, which are summarized in Tables 3 and 4

season discharge is taken as low-flow discharge. The regional significance was determined by means of expert judgement, taking into account a combination of objective and subjective criteria. This prioritization by regional experts helped to decide whether or not a particular spring would be included in the final map.

The final map will include the following types of springs: selected karst springs with low-flow discharge $\geq 2 \mathrm{~m}^{3} / \mathrm{s}$, selected springs with low-flow discharge $<2$ $\mathrm{m}^{3} / \mathrm{s}$, selected water wells and other abstraction structures, selected submarine springs, selected thermal and mineral springs.

Depending on the printing scale, the final selection of springs and wells will be adapted. For special maps that might be published later (e.g. karst map of a particular continent, country or region; thematic special maps), the existing detailed database can be used and complemented, and the criteria for inclusion on the map can be adapted accordingly-for example, based on the WOKAM spring database, Stevanovic et al. (2016) have published regional karst water sources maps for South East Europe, Near and Middle East, and Eastern Africa.

\section{Cave database}

Several books (e.g. Palmer and Palmer 2009; Courbon 1989; Laumanns 2002) and Internet resources (Gulden 2016)
Table 3 Summary of selected springs in the example area (France and neighboring regions), shown on the map in Fig. 8. Quantitative estimations for low-flow and high-flow discharge $\left(\mathrm{m}^{3} / \mathrm{s}\right)$ are indicated

\begin{tabular}{|c|c|c|c|}
\hline ID & Name of spring & Low $\left[\mathrm{m}^{3} / \mathrm{s}\right]$ & $\operatorname{High}\left[\mathrm{m}^{3} / \mathrm{s}\right]$ \\
\hline 1 & Vaucluse spring & 4.0 & 150 \\
\hline 2 & Touvre spring & 6.0 & 40 \\
\hline 3 & Loue spring & 0.9 & 75 \\
\hline 4 & Bouillon spring & 2.5 & 20 \\
\hline 5 & Foux de la Vis spring & 1.2 & 245 \\
\hline 6 & Port-Miou submarine spring & 3.0 & 50 \\
\hline 7 & Fontaine L'Evêque spring & 2.3 & 19 \\
\hline 8 & Lison spring & 0.4 & 91 \\
\hline 9 & Gillardes spring & 3.0 & 60 \\
\hline 10 & Chartreux spring & 1.0 & 50 \\
\hline 11 & Arbois spring & 1.7 & 40 \\
\hline 12 & Bèze spring & 0.9 & 25 \\
\hline 13 & Source Bleue and related springs & 2.0 & 5 \\
\hline 14 & Ouysse spring & 0.6 & 200 \\
\hline 15 & Fontestorbes spring & 0.6 & 15 \\
\hline 16 & Groin spring & 0.0 & 104 \\
\hline 17 & Font de Champdamoy spring & 0.2 & 18 \\
\hline 18 & Douix spring & 0.6 & 3 \\
\hline 19 & Lez spring & 0.5 & 16 \\
\hline 20 & Arcier spring & 0.2 & 10 \\
\hline 21 & Font Estramar spring & 0.8 & 25 \\
\hline 22 & Doubs spring & 0.2 & 19 \\
\hline 23 & Durzon spring & 1.0 & 20 \\
\hline 24 & Archiane spring & 0.1 & 21 \\
\hline 25 & Fontaine de Nîmes spring & 0.0 & 18 \\
\hline 26 & Aliou spring & 0.0 & 32 \\
\hline 27 & Areuse spring (Switzerland) & 0.7 & 39 \\
\hline 28 & Orbe spring (Switzerland) & 2.0 & 80 \\
\hline
\end{tabular}

present useful information on the longest and deepest caves in the world or in particular regions or countries. Although the focus of WOKAM is not on caves but on water resources, caves will also be displayed on the final map, insofar as caves

Table 4 Summary of selected caves in France, shown on the map in Fig. 8. Caves are characterized by length $(\mathrm{km})$ and depth $(\mathrm{m})$

\begin{tabular}{llcl}
\hline ID & Name of cave & Length $[\mathrm{km}]$ & Depth [m] \\
\hline 1 & Saint-Marcel d'Ardèche cave & 51.2 & 233 \\
2 & Dent de Crolles cave system & 50.1 & 673 \\
3 & Coume Ouarnède cave system & 105.8 & 975 \\
4 & Jean Bernard cave system & 20.5 & 1,602 \\
5 & Clot d'Aspres cave system & 40.0 & 1,066 \\
6 & Pierre Saint-Martin cave system & 80.2 & 1,408 \\
\hline
\end{tabular}




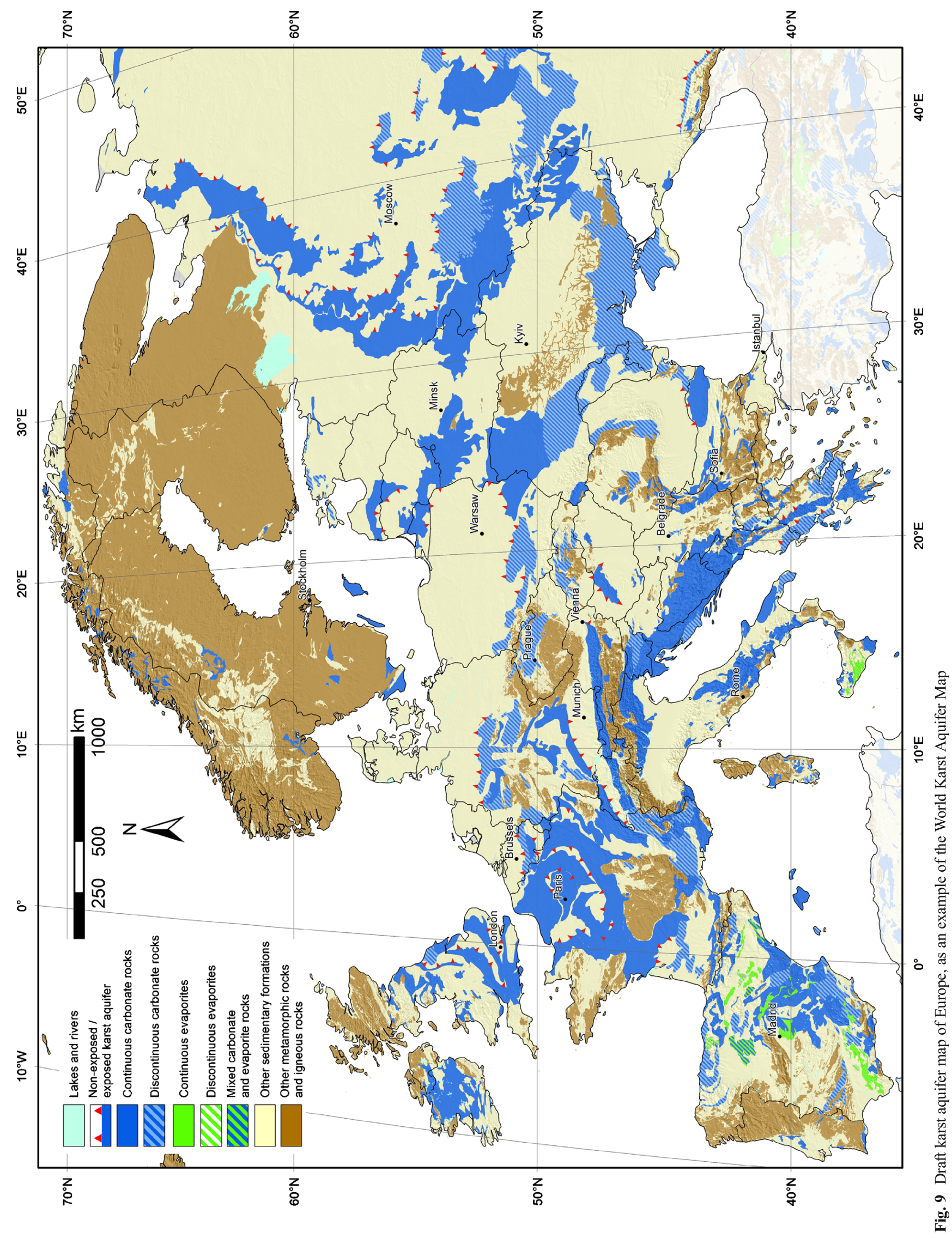


Table 5 Estimated distribution of carbonate rocks in all European countries, differentiated in continuous $(>65 \%)$ and discontinuous (15-65\%) carbonate rock, as presented on the map in Fig. 9. The area of actual carbonate outcrops (derived from the non-generalized polygons) is also presented. Uncertain data are marked in italics

\begin{tabular}{|c|c|c|c|c|c|c|c|c|c|}
\hline \multicolumn{2}{|l|}{ Country } & \multicolumn{8}{|c|}{ Carbonate rock areas } \\
\hline \multirow[t]{2}{*}{ Name } & \multirow{2}{*}{$\begin{array}{l}1,000 \\
\mathrm{~km}^{2}\end{array}$} & \multicolumn{2}{|c|}{ Continuous } & \multicolumn{2}{|c|}{ Discontinuous } & \multicolumn{2}{|c|}{$\operatorname{Sum}(C C+D C)$} & \multicolumn{2}{|c|}{ Outcrops } \\
\hline & & $\begin{array}{l}1,000 \\
\mathrm{~km}^{2}\end{array}$ & $\%$ & $\begin{array}{l}1,000 \\
\mathrm{~km}^{2}\end{array}$ & $\%$ & $\begin{array}{l}1,000 \\
\mathrm{~km}^{2}\end{array}$ & $\%$ & $\begin{array}{l}1,000 \\
\mathrm{~km}^{2}\end{array}$ & $\%$ \\
\hline Albania & 28.7 & 9.9 & 34.6 & 4.1 & 14.4 & 14.1 & 49.0 & 9.8 & 34.3 \\
\hline Andorra & 0.5 & 0.0 & 0.0 & 0.0 & 0.0 & 0.0 & 0.0 & 0.0 & 0.0 \\
\hline Austria & 83.9 & 23.7 & 28.2 & 0.0 & 0.0 & 23.7 & 28.2 & 20.9 & 25.0 \\
\hline Belarus & 207.3 & 66.1 & 31.9 & 0.0 & 0.0 & 66.1 & 31.9 & 52.1 & 25.1 \\
\hline Belgium & 30.6 & 3.5 & 11.6 & 6.0 & 19.6 & 9.5 & 31.2 & 3.8 & 12.4 \\
\hline $\begin{array}{l}\text { Bosnia and } \\
\text { Herzegovina }\end{array}$ & 51.5 & 39.9 & 77.5 & 0.0 & 0.0 & 39.9 & 77.5 & 31.2 & 60.5 \\
\hline Bulgaria & 111.1 & 30.2 & 27.2 & 0.2 & 0.2 & 30.4 & 27.4 & 30.1 & 27.1 \\
\hline Croatia & 55.9 & 23.5 & 42.0 & 4.7 & 8.5 & 28.2 & 50.5 & 22.8 & 40.9 \\
\hline Czech Republic & 78.7 & 0.0 & 0.0 & 15.0 & 19.0 & 15.0 & 19.0 & 7.2 & 9.2 \\
\hline Denmark & 42.6 & 0.0 & 0.0 & 0.0 & 0.0 & 0.0 & 0.0 & 0.0 & 0.1 \\
\hline Estonia & 45.8 & 0.5 & 1.2 & 4.3 & 9.4 & 4.9 & 10.6 & 1.1 & 2.4 \\
\hline Finland & 333.9 & 0.2 & 0.1 & 0.0 & 0.0 & 0.2 & 0.1 & 0.2 & 0.1 \\
\hline France & 547.9 & 227.8 & 41.6 & 44.0 & 8.0 & 271.8 & 49.6 & 191.9 & 35.0 \\
\hline Germany & 356.7 & 35.7 & 10.0 & 40.7 & 11.4 & 76.4 & 21.4 & 37.6 & 10.5 \\
\hline Greece & 130.2 & 30.0 & 23.0 & 23.4 & 18.0 & 53.4 & 41.0 & 35.3 & 27.1 \\
\hline Hungary & 92.9 & 8.8 & 9.5 & 0.4 & 0.4 & 9.2 & 9.9 & 3.9 & 4.2 \\
\hline Iceland & 102.5 & 0.0 & 0.0 & 0.0 & 0.0 & 0.0 & 0.0 & 0.0 & 0.0 \\
\hline Ireland (Republic) & 69.5 & 32.4 & 46.6 & 0.0 & 0.0 & 32.4 & 46.6 & 23.9 & 34.4 \\
\hline Italy & 300.2 & 78.6 & 26.2 & 5.8 & 1.9 & 84.4 & 28.1 & 57.4 & 19.1 \\
\hline Latvia & 64.5 & 8.6 & 13.3 & 0.0 & 0.0 & 8.6 & 13.3 & 7.7 & 12.0 \\
\hline Liechtenstein & 0.2 & 0.2 & 96.5 & 0.0 & 0.0 & 0.2 & 96.5 & 0.1 & 51.1 \\
\hline Lithuania & 64.9 & 18.6 & 28.6 & 0.0 & 0.0 & 18.6 & 28.6 & 15.7 & 24.1 \\
\hline Luxembourg & 2.6 & 1.7 & 65.1 & 0.0 & 0.0 & 1.7 & 65.1 & 1.6 & 61.1 \\
\hline Malta & 0.3 & 0.3 & 93.8 & 0.0 & 0.0 & 0.3 & 93.8 & 0.3 & 93.8 \\
\hline Montenegro & 13.8 & 11.7 & 85.3 & 0.0 & 0.0 & 11.7 & 85.3 & 11.0 & 80.1 \\
\hline Netherlands & 34.9 & 0.0 & 0.0 & 0.3 & 0.8 & 0.3 & 0.8 & 0.1 & 0.2 \\
\hline $\begin{array}{l}\text { Norway (incl. } \\
\text { Svalbard) }\end{array}$ & 382.1 & 12.1 & 3.2 & 1.0 & 0.3 & 13.1 & 3.5 & 10.0 & 2.6 \\
\hline Poland & 311.2 & 15.8 & 5.1 & 30.6 & 9.8 & 46.4 & 14.9 & 21.6 & 6.9 \\
\hline Portugal & 91.3 & 3.5 & 3.8 & 0.4 & 0.4 & 3.8 & 4.2 & 3.7 & 4.0 \\
\hline $\begin{array}{l}\text { Republic of } \\
\text { Macedonia }\end{array}$ & 25.5 & 2.2 & 8.6 & 3.0 & 11.8 & 5.2 & 20.4 & 3.2 & 12.4 \\
\hline $\begin{array}{r}\text { Republic of } \\
\text { Moldova }\end{array}$ & 33.7 & 0.0 & 0.0 & 16.5 & 49.1 & 16.5 & 49.1 & 6.0 & 17.8 \\
\hline Romania & 237.3 & 6.3 & 2.7 & 21.0 & 8.8 & 27.3 & 11.5 & 5.5 & 2.3 \\
\hline Russia (Europ. part) & $4,002.0$ & 495.7 & 12.4 & 193.2 & 4.8 & 688.8 & 17.2 & 454.3 & 11.4 \\
\hline Serbia and Kosovo & 88.2 & 16.9 & 19.2 & 0.8 & 1.0 & 17.8 & 20.2 & 15.8 & 17.9 \\
\hline Slovakia & 48.9 & 0.2 & 0.5 & 10.2 & 20.8 & 10.4 & 21.3 & 4.3 & 8.9 \\
\hline Slovenia & 20.4 & 10.3 & 50.6 & 5.8 & 28.5 & 16.2 & 79.1 & 10.1 & 49.5 \\
\hline Spain & 499.1 & 96.3 & 19.3 & 49.5 & 9.9 & 145.7 & 29.2 & 70.6 & 14.1 \\
\hline Sweden & 444.3 & 14.7 & 3.3 & 0.0 & 0.0 & 14.7 & 3.3 & 12.4 & 2.8 \\
\hline Switzerland & 41.5 & 14.8 & 35.7 & 1.1 & 2.6 & 15.9 & 38.3 & 7.9 & 19.0 \\
\hline Turkey & 23.8 & 1.7 & 7.2 & 0.0 & 0.0 & 1.7 & 7.2 & 1.7 & 7.2 \\
\hline $\begin{array}{l}\text { UK (incl. N. } \\
\text { Ireland) }\end{array}$ & 243.8 & 64.2 & 26.3 & 3.5 & 1.5 & 67.7 & 27.8 & 51.1 & 21.0 \\
\hline Ukraine & 597.0 & 90.1 & 15.1 & 156.6 & 26.2 & 246.7 & 41.3 & 123.4 & 20.7 \\
\hline Europe total & $9,941.7$ & $1,497.0$ & 15.1 & 642.1 & 6.5 & $2,139.1$ & 21.6 & $1,367.4$ & 13.8 \\
\hline
\end{tabular}

deliver information on the degree of karstification, although there is no simple and straightforward relation between cave development and karst aquifer properties (Palmer 1991). The global distribution of caves is even more heterogeneous than the distribution of springs, because the regional frequency, length and depth of caves also reflect the degree of exploration, which varies hugely between countries. In some small European countries such as Switzerland or Slovenia, there are thousands of mapped caves, including large ones, whereas large carbonate rock areas in some remote regions of our planet have almost no known caves. This uneven spatial distribution and degree of information makes it very difficult to define strictly objective and applicable criteria for the 
selection of caves for the world karst aquifer map; therefore, a pragmatic weighting and rating approach was established, taking into account the dimensions of the cave (mapped length and depth), and its hydrological significance, role for human use and ecosystems, and regional significance (Table 1).

Depending on the scale of the final map, different thresholds can be defined for including caves from the database, e.g. six points could be the minimum value for inclusion on the 1:25 million map. Table 2 illustrates this point-count system by means of five examples. Some caves (e.g. SiebenhengsteHohgant System in Switzerland) are primarily included on the map because of their dimensions ( $>100 \mathrm{~km}$ long and $>1,000$ $\mathrm{m}$ deep); other caves (e.g. Sof Omar Cave in Ethiopia) are included because of their regional significance (longest cave in Africa), hydrological significance (a river flows through this cave) and its importance for human use and ecosystems (Asrat 2015).

\section{Karst aquifer map of France with springs and caves}

The selection and cartographic presentation of significant springs and caves is illustrated for the example region (France) in Fig. 8; Tables 3 and 4 present a summary of these selected objects. Springs are characterized by their low-flow and high-flow discharge $\left(\mathrm{m}^{3} / \mathrm{s}\right)$; for caves, the surveyed lengths $(\mathrm{km})$ and depths $(\mathrm{m})$ are indicated.

\section{Draft karst aquifer map of Europe}

Figure 9 presents the draft karst aquifer map of Europe in the preliminary design of WOKAM at a scale of 1:25 million, using the Sphere Robinson projection. The map is presented without springs and caves, as the database has not yet been completed for all European countries. Based on the statistical evaluation of this map, it is possible to determine the areas of carbonate rocks. For this analysis, the map projection was changed to Eckert IV (equal area). Table 5 presents the absolute surfaces (in $1,000 \mathrm{~km}^{2}$ ) and the percentage of carbonate rock areas in all European countries and in Europe as a whole. The table differentiates between "continuous" and "discontinuous" carbonate rock areas, as defined in WOKAM, and also presents the sum of both, i.e. the total area characterized by the presence of (continuous or discontinuous) carbonate rocks. The surface of actual carbonate outcrops is also presented and was obtained from the non-generalized polygons.

According to this analysis, $15.1 \%$ of the land surface consists of "continuous carbonate rocks" and $6.5 \%$ consists of "discontinuous carbonate rocks." Accordingly, $21.6 \%$ of the European land surface is characterized by the presence of carbonate rock, most of which is karstified and forms karst aquifers. The total area share of actual carbonate rock outcrops (generally derived from the non-generalized polygons) is about $13.8 \%$. The areas of non-exposed karst aquifers cannot be delineated precisely, but the map allows identification of their locations. These numbers include all uncertainties involved in the entire process of generating the map - from the initial mapping in the field to the final classification and generalization in WOKAM.

In 1995, the European Cooperation in Science and Technology (COST) Action 65 prepared a draft map of carbonate rock outcrops in Europe and estimated that $35 \%$ of the European land surface consists of carbonate rocks (COST Action 65 1995). The main reason for the discrepancy is that WOKAM is based on a much better cartographic database and differentiates between areas of discontinuous and continuous carbonate rocks, taking into account the actual surface areas of carbonate rocks.

\section{Conclusions}

Karst is an expansive terrain that occurs on all continents. Its aquifers produce the world's largest springs while being the most vulnerable to contamination. Karst aquifers often cross international boundaries but until recently, the boundaries of karst were often poorly defined. Building on the Global Lithological Map (Hartmann and Moosdorf 2012) and growing databases and exploration of karst, and through the use of versatile GIS technology, the first World Karst Aquifer Map (WOKAM) is nearing completion. This paper describes the basic concepts and procedure of this world-wide mapping effort and examines a subset of the World Karst Aquifer Map by focusing on Europe.

WOKAM is prepared at a consistent working scale of 1:10 million and differentiates between areas of "continuous carbonate rocks" (typically $>65 \%$ carbonate rock outcrops) and "discontinuous carbonate rocks" (typically $15-65 \%$ outcrops). The updip boundaries of non-exposed karst aquifers are also delineated on WOKAM. The map and associated database include selected karst springs, wells and other freshwater abstraction structures, and selected caves.

As a well-studied continent with rich sources of information, Europe was an ideal region to test, refine, and prove the mapping concepts for WOKAM. Prior estimates that carbonate rock outcrops cover 35\% of Europe were found to be overestimates by the more accurate WOKAM process. It was found that about $21.6 \%$ of the European land surface is characterized by the presence of carbonate rock, including $15.1 \%$ of "continuous" and $6.5 \%$ of "discontinuous carbonate rocks". The total area of actual carbonate rock outcrops is about $13.8 \%$. Much of this occurs beneath some of the continent's most densely populated regions where effective water-resource management is especially critical, such as England (UK), northern and southern France, parts of Germany, central Italy, and eastern Spain.

The georeferenced GIS structure of WOKAM and the associated database will allow its relatively easy updating and 
will make it possible to prepare specific maps by combining information presented on WOKAM with other relevant information such as climate and global change, agriculture and irrigation, population density and water demand, or biodiversity. WOKAM and the subsequent special maps will make it possible to better define, understand and properly manage the world's karst aquifers and their associated natural resources.

Acknowledgements The WOKAM project is part of the World-wide Hydrogeological Mapping and Assessment Programme (WHYMAP) executed under the umbrella of the UNESCO International Hydrological Programme (UNESCO-IHP). The project was financially supported by IAH and UNESCO and elaborated in cooperation with the WHYMAP team at BGR. We thank Wilhelm Struckmeier (IAH Past President) for initiating this project. We thank Alice Aureli and Aurélien Dumont (UNESCO) and Stefan Broda (BGR) for friendly support and cooperation. Paul Williams, Alexander Klimchouk and Yuan Daoxian contributed as remote advisors, by discussions and suggestions. Many regional experts delivered data or helped to evaluate the map for different regions in Europe: Romeo Eftimi (Albania), Boban Jolović (Bosnia and Herzegovina), Aleksey Benderev (Bulgaria), Želimir Pekaš (Croatia), Judit Mádl-Szőny (Hungary), Jo De Waele, Francesco Fiorillo (Italy), Milan Radulović (Montenegro), Jacek Rózkowski (Poland), Costa Almeida, António Chambel (Portugal), Iancu Orășeanu (Romania), Alexander Osintsev, Gennady Amelichev, Nikolay Maksimovich, Andrey Ostapenko, Vladimir Rezvan, Eugeny Zakharov and Andrei Filippov (Russia), Peter Malik (Slovakia), Nataša Ravbar (Slovenia) and Juan Jose Duran and Bartolomé Andreo Navarro (Spain). Andreas Tide (KIT) contributed as a student assistant. Colleagues who delivered data from other continents will be acknowledged when we present the final World Karst Aquifer Map.

Open Access This article is distributed under the terms of the Creative Commons Attribution 4.0 International License (http:// creativecommons.org/licenses/by/4.0/), which permits unrestricted use, distribution, and reproduction in any medium, provided you give appropriate credit to the original author(s) and the source, provide a link to the Creative Commons license, and indicate if changes were made.

\section{References}

Al-Charideh A (2012) Recharge rate estimation in the mountain karst aquifer system of Figeh spring, Syria. Environ Earth Sci 65:1169-1178

Almeida C, Silva M L, Crispim JA (1995) National report for Portugal. In: Final report COST action 65, Hydrogeological aspects of groundwater protection in karstic areas. Dir-General Science, Research and Development, Lisbon, pp 211-220

Asrat A (2015) Geology, geomorphology, geodiversity and geoconservation of the Sof Omar Cave System, southeastern Ethiopia. J Afr Earth Sci 108:47-63

Ayala-Carcedo FJ (1986) Mapa del karst de España [Karst map of Spain]. Instituto Geológico y Minero de España, Madrid

Bakalowicz M (2005) Karst groundwater: a challenge for new resources. Hydrogeol J 13:148-160

Beccaletto L, Hanot F, Serrano O, Marc S (2011) Overview of the subsurface structural pattern of the Paris Basin (France): insights from the reprocessing and interpretation of regional seismic lines. Marine Petroleum Geol 28(4):861-879
Beron P, Daaliev T, Jalov A (2006) Caves and Speleology in Bulgaria, PenSoft, Bulgarian Federation of Speleology and National Museum of Natural History, Sofia, Bulgaria, $507 \mathrm{pp}$

Bonacci O (1987) Karst Hydrology with special references to the Dinaric Karst. Springer, Berlin

BGR (2016) World-wide Hydrogeological Mapping and Assessment Programme (WHYMAP). http://www.whymap.org . Accessed on June 24, 2016

COST Action 65 (1995) Karst groundwater protection. Final report EUR 16547, European Commission, Brussels, 446 pp

Courbon P (1989) Atlas of the great caves of the world. Cave Books, St. Louis, MO

Drew D, Hötzl H (1999) Karst hydrogeology and human activities: impacts, consequences and implications. IAH International Contributions to Hydrogeology 20, Taylor and Francis, London

Duscher K, Gunther A, Richts A, Clos P, Philipp U, Struckmeier W (2015) The GIS layers of the "International Hydrogeological Map of Europe 1:1,500,000" in a vector format. Hydrogeol J 23:1867-1875

Ford D, Williams DW (1989) Karst geomorphology and hydrology. Hyman, Boston

Ford D, Williams P (2007) Karst hydrogeology and geomorphology. Wiley, Chichester, UK

Goeppert N, Goldscheider N, Scholz H (2011) Karst geomorphology of carbonatic conglomerates in the Folded Molasse zone of the Northern Alps (Austria/Germany). Geomorphology 130:289-298

Goldscheider N, Drew D (2007) Methods in karst hydrogeology. Taylor and Francis, London

Goldscheider N, Madl-Szonyi J, Eross A, Schill E (2010) Review: Thermal water resources in carbonate rock aquifers. Hydrogeol $\mathrm{J}$ 18:1303-1318

Gulden B (2016) Lists of longest and deepest caves in the world. http://www.caverbob.com. Accessed June 24, 2016

Guo F, Jiang G, Yuan D, Polk JS (2013) Evolution of major environmental geological problems in karst areas of southwestern China. Environ Earth Sci 69:2427-2435

Hartmann A, Goldscheider N, Wagener T, Lange J, Weiler M (2014) Karst water resources in a changing world: review of hydrological modeling approaches. Rev Geophys 52:218242

Hartmann J, Moosdorf N (2012) The new global lithological map database GLiM: a representation of rock properties at the Earth surface. Geochem Geophys Geosyst 13(12). doi:10.1029/2012GC004370

Hollingsworth E (2009) Karst regions of the world (KROW): populating global karst datasets and generating maps to advance the understanding of karst occurrence and protection of karst species and habitats worldwide. University of Arkansas, Little Rock, AK, 139 pp

Hungarian Ministry of Interior (2016) Online geo information system for Hungary. www.vizugy.hu. Accessed on June 24, 2016

Jeannin P-Y (2016) Main karst and caves of Switzerland. Bol Geol Min 127(1):45-46

Kauahikaua J, Cashman KV, Mattox TN, Heliker CC, Hon KA, Mangan MT, Thornber CR (1998) Observations on basaltic lava streams in tubes from Kilauea Volcano, island of Hawai'i. J Geophys Res Solid Earth 103:27303-27323

Kozary MT, Dunlap JC, Humphrey WE (1968) Incidence of saline deposits in geologic time. Geol Soc Am Spec Pap 88:43-57

Kresic N, Stevanovic Z (2010) Groundwater hydrology of springs: engineering, theory, management, and sustainability. ButterworthHeinemann, Oxford, UK

Kubota T, Shige S, Hashizurne H, Aonashi K, Takahashi N, Seto S, Hirose M, Takayabu YN, Ushio T, Nakagawa K, Wanami K, Kachi M, Okamoto Ki (2007) Global precipitation map using satellite-borne microwave radiometers by the GSMaP 
project: production and validation. IEEE Trans Geosci Remote Sens 45:2259-2275

Laumanns M (2002) Atlas of the great caves and the karst of Africa, 1st edn. Berliner Höhlenkundliche Berichte, vols 7-9, Speläoclub Berlin, Berlin

Lehner B, Liermann CR, Revenga C, Voeroesmarty C, Fekete B, Crouzet P, Doell P, Endejan M, Frenken K, Magome J, Nilsson C, Robertson JC, Roedel R, Sindorf N, Wisser D (2011) High-resolution mapping of the world's reservoirs and dams for sustainable river-flow management. Front Ecol Environ 9:494-502

Maurice LD, Atkinson TC, Barker JA, Bloomfield JP, Farrant AR, Williams AT (2006) Karstic behaviour of groundwater in the English Chalk. J Hydrol 330:63-70

Moosdorf N, Hartmann J (2015) Lithological map of the World. Commission of the Geological Map of the World (CGMW), Paris

Orășeanu I, Iurkiewicz A (2010) Karst hydrogeology of Romania, Oradea, Romania

Palmer AN (1991) Origin and morphology of limestone caves. Geol Soc Am Bull 103:1-21

Palmer AN, Palmer MV (2009) Caves and karst of the USA. National Speleological Society, Huntsville, AL

Piccini L, Mecchia M (2009) Solution weathering rate and origin of karst landforms and caves in the quartzite of Auyan-tepui (Gran Sabana, Venezuela). Geomorphology 106:15-25

Ravbar N, Šebela S (2015) The effectiveness of protection policies and legislative framework with special regard to karst landscapes: insights from Slovenia. Environ Sci Pol 51:106-116

Richts A, Struckmeier W, Zaepke M (2011) WHYMAP and the groundwater resources map of the world 1:25,000,000. In: Anthony J, Jones A (eds) Sustaining groundwater resources: a critical element in the global water crisis. International Year of Planet Earth, Springer, Heidelberg, Germany, pp 159-173

Rimmer A, Salingar Y (2006) Modelling precipitation-streamflow processes in karst basin: the case of the Jordan River sources, Israel. J Hydrol 331:524-542

Sivelli M, De Waele J (eds) (2013) A journey across speleological Italy. Map in scale 1:1.500,000. Supplement to Speleologia 68, Società Speleologica Italiana, Bologna, Italy
Skoglund RO, Lauritzen S-E (2011) Subglacial maze origin in low-dip marble stripe karst: examples from Norway. J Cave Karst Stud 73:31-43

Stevanovic Z (2015) Karst aquifers: characterization and engineering. Professional Practice in Earth Sciences, Springer, Heidelberg, Germany, $692 \mathrm{pp}$

Stevanovic Z, Jemcov I (1996) Digital hydrogeological map of Yugoslavia (in Serbian). Proceedings of the XI Yugoslavian Symposium on hydrogeology and engineering geology, vol 1, Budva, Montenegro, pp 163-170

Stevanovic Z, Goldscheider N, Chen Z and the WOKAM Team (2016) WOKAM: the world karst aquifer mapping project, examples from South East Europe, Near and Middle East and Eastern Africa. In: Stevanovic Z, Kresic N, Kukuric N (eds) Karst without boundaries. CRC, Boca Raton, FL, pp 39-51

UNESCO-IHP (2013) Protection and sustainable use of the Dinaric Karst Transboundary Aquifer System, transboundary diagnostic analysis. UNESCO-IHP, Paris

US Geological Survey (2016) Geologic provinces of the world. http://certmapper.cr.usgs.gov/data/wep/dds60/wep_prv.htm. Accessed on June 24, 2016

WHYMAP (2008) Groundwater resources of the world, 1:25,000, 000. World-wide Hydrogeological Mapping and Assessment Programme (WHYMAP) Consortium. BGR, Hannover and UNESCO, Paris

Williams P, Fong YT (2016) World map of carbonate rock outcrops v3.0. http://web.env.auckland.ac.nz/our_research/karst. Accessed on June 24, 2016

Williams PW, Ford DC (2006) Global distribution of carbonate rocks. Zeitschrift für Geomorphologie 147(Suppl):1-2

Wu P, Tang C, Zhu L, Liu C, Cha X, Tao X (2009) Hydrogeochemical characteristics of surface water and groundwater in the karst basin, Southwest China. Hydrol Process 23:2012-2022

Yamazaki D, Oki T, Kanae S (2009) Deriving a global river network map and its sub-grid topographic characteristics from a fine-resolution flow direction map. Hydrol Earth Syst Sci 13:2241-2251 